\title{
The Effect of Good Corporate Governance, Return On Asset, and Firm Size on Firm Value in LQ45 Company Listed in Indonesia Stock Exchange
}

\author{
Marlina Widiyanti ${ }^{1}$, Nicka Saputri ${ }^{1}$, Reza Ghasarma ${ }^{1}$ and Endang Sriyani ${ }^{2}$ \\ \{marlinawidiyanti68@yahoo.co.id ${ }^{1}$, endangsriyani.nurdin@gmail.com ${ }^{2}$ \} \\ ${ }^{1}$ Faculty of Economy, Universitas Sriwijaya, Palembang, Indonesia \\ ${ }^{2}$ Department of Economy, Sekolah Tinggi Ilmu Ekonomi Rahmaniyah, Palembang, Indonesia
}

\begin{abstract}
This research objective was to know the influence of Good Corporate Governance, Return On asset, and Firm Size to Firm Value On Company Registered in LQ45. Population The Grand Theory in this research are Agency Theory and Signaling Theory. Sampling method used is Purposive Sampling. The population of this research ware 45 companies of LQ45 and the sampples ware 12 companies of LQ45 indonesia during the period of 2012-2015. Data Analysis Technique used was Multiple Regression Linear. This results partially showed that Good Corporate Governance and Firm Size had negative effect on Firm Value, while Return On Asset had posittive effect on Firm Value. While the results showed that Good Corporate Governance, Return On Asset, and Size had significant and positive effects to Firm Value. The implication of this research is Return On Asset has a dominant effect on firm value. The was high Return On Asset can cover the Good Corporate Governance and the Firm size of the company wrote the low, it can be seen from the magnitude of property owned. As the result those factors become the important thing for investors to invest in the company.
\end{abstract}

Keywords : Firm Value, Good Corporate Governance (GCG), Return On asset (ROA), Firm Size

\section{Introduction}

The economic crisis in 1997 that hit Indonesia made Indonesia's economic condition chaotic and experienced a significant decline. This is seen from the many bankrupt companies, the bad performance of the national banking, the number of bad credit financing, the low competitiveness of Indonesian products with foreign products, to the fear of owners and management of companies and governments against the various consequences that will arise from the free trade.

Ethical standards in business can be done by the implementation of Corporate Governance. Adrian Sutedi defines Good Corporate Governance as a set of rules that establishes relationships between shareholders, managers, creditor, government, employees and other internal and external stakeholders in respect of their rights and obligations, or in other words directing and controlling the company [1]. 
Good Corporate Governance is concerned with people (morality), work ethics, and good working principles. Companies that sincerely and purely implement Good Corporate Governance will automatically have endurance from internal and external threats. Companies with the principles of Good Corporate Governance have positive values to maintain consistency and professionalism of the firm.

Table 1. GCG Average Progress, ROA, Firm Size, and Corporate Value (Tobin's Q) At LQ45 Firm period 2012-2015

\begin{tabular}{ccccc}
\hline Year & $\begin{array}{c}\text { Good } \\
\text { Corporate } \\
\text { Governance } \\
\text { (GCG) }\end{array}$ & $\begin{array}{c}\text { Return On } \\
\text { Asset (ROA) }\end{array}$ & $\begin{array}{c}\text { Firm } \\
\text { Size }\end{array}$ & Tobin's $\boldsymbol{Q}$ \\
\hline $\mathbf{2 0 1 2}$ & 79,78 & 116,285 & 18,786 & 3,409 \\
$\mathbf{2 0 1 3}$ & 79,78 & 13,490 & 19,904 & 4,098 \\
$\mathbf{2 0 1 4}$ & 83,40 & 14,618 & 17,368 & 3,742 \\
$\mathbf{2 0 1 5}$ & 75,54 & 13,072 & 18,354 & 3,211 \\
Average & 78,298 & 14,367 & 18,603 & 3,615 \\
\hline
\end{tabular}

This formulation of the problem ari how does the influence of Good Corporate Governance, Return On Assets, and the size of the firm to the firm value partially on firms listed in LQ45 period 2012-2015 and what is the effect of Good Corporate Governance, Return On Assets, and firm size on the value of the firm jointly on the firms listed in LQ45 period 2012-2015.

\section{LITERATURE STUDIES}

\subsection{Agency Theory}

Agency theory is the underlying theoretical basis of the company's business practices. Agency theory is a contractual relationship between one or several people (principal / owner of the company), with others as agents (managers) who include the authority to perform tasks for the principal interests, especially in taking a decision [2] [3].

\subsection{Signaling Theory}

Management always strives to disclose private information which, according to its consideration, is in great demand by investors and shareholders, especially if the information is good news. Signaling theory emphasizes that companies will tend to present more complete information to obtain a better reputation than firms that do not disclose, and it will eventually attract investors [4].

\subsection{The Value of Firm}

Companies established for the purpose of increasing the firm value. The value of the company will be reflected from the stock price. the higher the stock price is, the higher the value of the company will be [5]. 


\subsection{Good Corporate Governance}

Defines Good Corporate Governance as a set of rules that establishes relationships between shareholders, managers, creditor, government, employees and other internal and external stakeholders in respect of their rights and obligations, or in other words directing and controlling the company [6] [7].

\subsection{Good Corporate Governance Assessment}

IICG (Indonesia Institute for Corporate Governance) harnesses the index as the basis for Good Corporate Governance assessment in the form of Corporate Governance Perception Index (CGPI) published in SWA magazine. The CGPI assessment includes four stages with value weights:
a. Self-assessment (15\%)
b. The Collection of Company Documents (25\%)
c. The Preparation of Papers and Presentations (12\%)
d. The Observations to the Company (48\%) 5.

\subsection{Benefits of Good Corporate Governance}

The implementation of Good Corporate Governance has several benefits in both short and long term as follows (Intan, 2010):

a. It can increase the value of the firm's share and improve the company's image.

b. It can reduce the cost to shareholders in relation to the delegation of authority to management to run the company.

c. It can reduce the capital cost of the company, which as a result of good corporate management is a decrease in corporate risk, resulting in decreased funds required or borrowed by the company.

d. It can increase support from the shareholders against various strategies and policies of the company that is considered more assured to be of maximum benefit to the company.

\subsection{Return On Asset}

Return On Assets (ROA) is the ratio that shows the results of the amount of assets used in the company (Cashmere, 2014).

$$
\mathrm{ROA}=\frac{\text { Net profit after tax deduction }}{\text { Total assets }} \times 100 \%
$$

Good Corporate Governance (GCG) as a set of rules establishing relationships between shareholders, managers, creditor, government, employees and other internal and external stakeholders in relation to their rights and obligations, or in other words the system that directs and controls company (Adrian Sutedi, 2012).

H1 = Good Corporate Governance positively affects the value of the Company.

This framework is designed to make it easier to understand the relationship between Good Corporate Governance (GCG), Return On Assets (ROA), and firm size to firm value. Based on the basic concepts of theory and the results of previous research. Then, the factors that can be used as indicators that affect the value of the company is Good Corporate Governance (GCG), Return On Assets (ROA), and company size. 


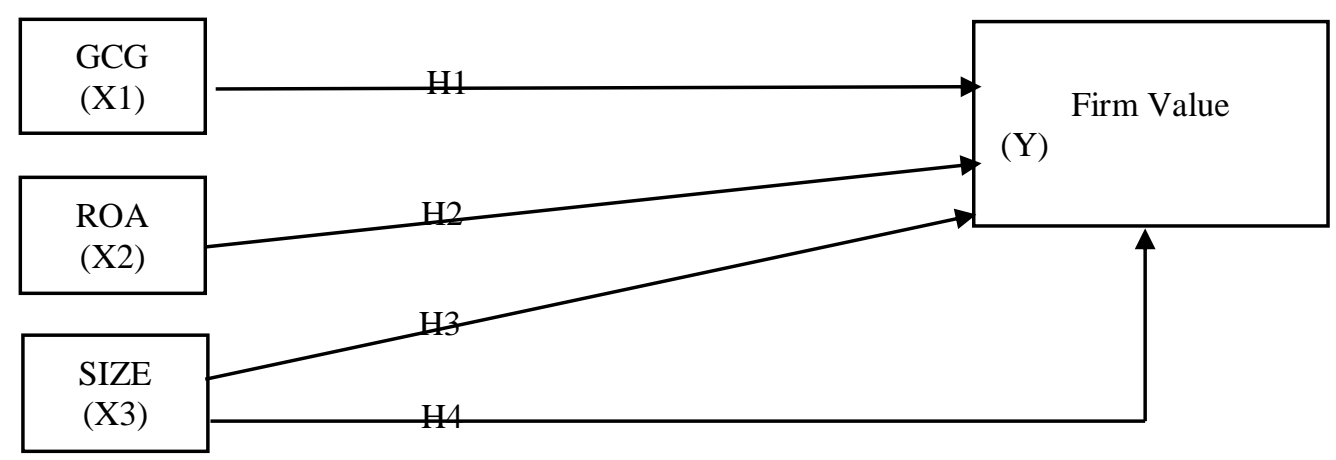

Fig. 1 Framework GCG and ROA

\section{RESEARCH METHODS}

The authors limit the scope of this study to the effects of independent rincipa, ie Good Corporate Governance, Return On Assets, and firm size to the dependent i.e firm value by using Tobin's Q in companies listed in LQ45 period 2012-2015.

\subsection{Research Design}

This study uses data contained in companies listed in LQ45. Period of data used is the financial statements of 2012 - 2015 (4 years).

Table 2. Definition Variable Scale Indicator Assessment

\begin{tabular}{|c|c|c|c|c|}
\hline No & Variable & Variabel definition & Scale & $\begin{array}{l}\text { Assessment } \\
\text { Indicator }\end{array}$ \\
\hline 1. & $\begin{array}{ll}\mathrm{Y}= & \text { Firm } \\
\text { Scale. } & \end{array}$ & $\begin{array}{l}\text { Firm value is a certain condition } \\
\text { that has been achieved by a } \\
\text { company as a picture of public } \\
\text { confidence to the company } \\
\text { through a process of activity for } \\
\text { several years. (Febry Nugroho, } \\
\text { 2013) }\end{array}$ & Ratio & $\begin{array}{c}\text { Tobin's } \mathrm{Q}= \\
\text { The market value of } \\
\text { equity }+ \\
\text { Book value of debt } \\
\begin{array}{r}\text { Total book value of } \\
\text { assets }\end{array}\end{array}$ \\
\hline 2. & $\begin{array}{l}\mathrm{X}_{1}=\text { Good } \\
\text { Corporate } \\
\text { Governance } \\
\text { (GCG). }\end{array}$ & $\begin{array}{l}\text { Good Corporate Governance is } \\
\text { defined as a set of rules that } \\
\text { establish relationships between } \\
\text { shareholders, managers, } \\
\text { creditors, government, } \\
\text { employees and other internal and } \\
\text { external stakeholders in respect } \\
\text { of their rights and obligations, or } \\
\text { in other words detailed that } \\
\text { direct and control the company }\end{array}$ & Scale & $\begin{array}{l}\text { Rating level on CGPI } \\
\text { - Very Trustworthy } \\
(85,00-100) \\
\text { - Trustworthy }(70,00 \\
-84.99) \\
\text { - Quite Trustworthy } \\
(55,00-69,99)\end{array}$ \\
\hline
\end{tabular}




\begin{tabular}{|c|c|c|c|c|}
\hline No & Variable & Variabel definition & Scale & $\begin{array}{l}\text { Assessment } \\
\text { Indicator }\end{array}$ \\
\hline & & [8]. & & \\
\hline 1. & $\begin{array}{l}\mathrm{X}_{2}=\text { Return } \\
\text { On Asset } \\
(\mathrm{ROA})\end{array}$ & $\begin{array}{l}\text { Return on Assets (ROA) is one } \\
\text { form of profitability ratio to } \\
\text { measure the ability of a } \\
\text { company to generate profits by } \\
\text { using the total existing assets } \\
\text { and after capital costs (the cost } \\
\text { of funding assets) which is } \\
\text { excluded from the analysis. }\end{array}$ & Ratio & $\begin{array}{l}\text { ROA Ratio = Profit } \\
\text { After Tax X 100\% : } \\
\text { total assets }\end{array}$ \\
\hline 2. & $\begin{array}{l}\mathrm{X} 3 \\
\text { Company } \\
\text { Size. }\end{array}$ & $\begin{array}{l}\text { The size of a company is a scale } \\
\text { which can be classified by the } \\
\text { size of the company in various } \\
\text { ways such as by total assets, log } \\
\text { size, stock market value, total } \\
\text { sales, monthly total average and } \\
\text { average of total funds. }\end{array}$ & Scale & $\begin{array}{l}\text { Size }=\text { Ln Total } \\
\text { Assets }\end{array}$ \\
\hline
\end{tabular}

\section{RESULTS AN DISCUSSION}

Based on raw data obtained from Corporate Governance Perpection Index (CGPI) and Indonesian Capital Market Directory (ICMD) in 2012-2015, data which can be obtained in this research such as Corporate Value (Tobins), Good Corporate Governance GCG), Return On Assets (ROA) and Company Size (Size) [9].

Table 3. Descriptive of Corporate Value (Tobins), Good Corporate Governance (GCG),

\begin{tabular}{lccccc}
\hline & N & Minimum & Maximum & Mean & $\begin{array}{c}\text { Std. } \\
\text { Deviation }\end{array}$ \\
\hline TOBINS & 48 & 0,24 & 27,72 & 3,6146 & 2,24601 \\
GCG & 48 & 71,19 & 88,70 & 78,2967 & 4,33687 \\
ROA & 48 & $-4,75$ & 40,38 & 14,3660 & 9,18335 \\
SIZE & 48 & 15,83 & 28,58 & 18,6031 & 3,42475 \\
Valid N (listwise) & 48 & & & &
\end{tabular}

Source: Result of Data Processed Statistics Program.

Based on the table above, it can be seen that minimum value of company value (Tobins) is 0.24 or $0.24 \%$ and the maximum value of company value (Tobins) is 27.72 or $27.72 \%$. From the table also shows that the average value (mean) value of the company (Tobins) is 3.61 or $3.61 \%$. Standard deviation of corporate value (Tobins) is 2.24 or $5.24 \%$. The average 
value is greater than the standard deviation. It means the value of the firm value variable is good.

Descriptive Analysis of Good Corporate Governance.

Based on the above table, it can be seen that the minimum value of Good Corporate Governance (GCG) is 71.19 or $71.19 \%$ and the maximum value of Good Corporate Governance (GCG) is 88.70 or $88.70 \%$. From the table, it is also seen that the average value (mean) Good Corporate Governance (GCG) is 78.29 or $78.29 \%$. Standard deviation of Good Corporate Governance (GCG) is 4.33 or $4.33 \%$. The average value is greater than the standard deviation, it can be said that the value of Good Corporate Governance (GCG) variable is good.

\section{Descriptive Analysis of Return on Assets}

Based on the table above, it can be seen that the minimum value of Return On Assets (ROA) is -4.75 or $-4.75 \%$ and the maximum value of Return On Assets (ROA) is 40.38 or $40.38 \%$. From table, it is also seen that mean value (mean) Return On Asset (ROA) equal to 14,36 or $14,36 \%$. Standard deviation Return On Assets (ROA) is 9.18 or $9.18 \%$. The average value is greater than the standard deviation, it means the value of the variable Return On Asset (ROA) is good.

\section{Descriptive Analysis of Firm Size}

Based on the table above, it can be seen that the minimum Size of the Company is 15.83 or $15.83 \%$ and the maximum value of Company Size (Size) is 28.58 or $28.58 \%$. From the table, it is also seen that mean value (mean) Size of Company (Size) equal to 18,60 or $18,60 \%$. Standard deviation of Company Size (Size) is 3.42 or $3.42 \%$. The average value is greater than the standard deviation, it means the value of the variable Size of the Company (Size) is also good.

\section{Good Corporate Governance (GCG) Influence on Corporate Value}

Based on the calculation of multiple linier regression test and partial research calculation ( $t$ test), value significance count is 0.193 . The value of calculated significance is greater than the value of significance which has been determined $(0,193>0,005)$. It means there is negative influence of Good Corporate Governance to company value.

2. Return on Asset Impact (ROA) on Corporate Value

Based on the calculation of multiple linier regression test and partial research calculation ( $\mathrm{t}$ test) which gained by significance value, it can be seen that it is 0.000 . The significance value result is smaller than the specified significance value $(0,000<0.05)$ which means there is a positive influence on the Return on Asset value of the company.

3. The Influence of Company Size (Size) on Corporate Value

Based on the calculation of multiple linear regression test, the significance value is 0.124 . The calculated significance value is greater than the specified significance value $(0.124>$ 0.05 ) which means there is a negative influence on firm value.

4. Discussion of Results of Collective Research (Test F)

Based on the results of calculations with simultaneously test that have been done using the results of data processing statistics program in Table 4.5 shows that significant $\mathrm{F}$ arithmetic is 19.294 and F Table is 2.81. This means F Count> F Table. The significant value is $=0.00>\alpha=0.05$. From these two things, it can be concluded that the variables of Good Corporate Governance, Return On Assets and size of the company (Size) affect the value of companies (Tobins) on LQ45 Company in 2012-2015 period simultaneously. 
The Adj column R2 in Table 4.5 has a value of 0.568 . Adj R2 is also called the coefficient of determination. The value of determination coefficient is 0,568 or $56,8 \%$ indicate that Good Corporate Governance variable, Return On Assets and company size able to explain company value detail equal to $56,8 \%$ and the rest equal to $43,2 \%$ explained by other details besides the detail proposed in this research.

Table 4. Summary of Research Results

\begin{tabular}{|c|c|c|}
\hline Influence & Research Results & Description \\
\hline $\begin{array}{l}\text { GCG has a negative and significant } \\
\text { effect on Firm Value }\end{array}$ & $\begin{array}{l}\text { Negative (-) and no significant } \\
\text { impact }\end{array}$ & Rejected \\
\hline $\begin{array}{l}\text { ROA has a positive and significant effect } \\
\text { on Firm Value }\end{array}$ & $\begin{array}{l}\text { positive }(+) \text { and significant } \\
\text { impact }\end{array}$ & Accepted \\
\hline Size negatively affects Firm Value & $\begin{array}{l}\text { Negative (-) and no significant } \\
\text { impact }\end{array}$ & Rejected \\
\hline $\begin{array}{l}\text { GCG, ROA, and Size affect the Firm } \\
\text { Value }\end{array}$ & Impact & Accepted \\
\hline $\begin{array}{l}\text { Return On Asset has dominant influence } \\
\text { to Firm Value }\end{array}$ & dominantly impact & Accepted \\
\hline
\end{tabular}

\section{CONCLUSION}

Based on the results of data analysis, it can be concluded several things as follows:

1. The results of the first hypothesis testing obtained value significance count is 0.287 . It can be concluded that there is a negative effect of Good Corporate Governance on the value of the company.

2. The result of second hypothesis testing obtained by significance value is 0.000 . There is a positive effect of Return On Assets on the value of the company.

3. The results of the third hypothesis testing obtained value significance count is 0.124 . There is a negative effect of firm size (Size) on firm value.

4. The research results also show that of the three independent variables (Good Corporate Governance, Return On Assets and Company Size), Return On Asset which has a dominant influence on Corporate Value with Beta 0.696.

5. Simultaneous test results show that the significance of $\mathrm{F}$ arithmetic is 0.000 . That the variables of Good Corporate Governance, Return On Assets and firm size simultaneously have a positive and significant effect on firm value.

\section{REFERENCE}

[1] S. Y. Abdillah, R. A. E. Susilawati, and N. Purwanto, "Pengaruh Good Corporate Governance Pada Manajemen Laba ( Studi Empiris pada Perusahaan Manufaktur yang Terdaftar di Bursa Efek Indonesia Tahun 2013-2014 ),” J. Ris. Mhs. Akunt., 2014.

[2] Ida Ayu Brahmasari and Agus Suprayetno, "Aplikasi Analisis Multivariate dengan program SPSS," Apl. Anal. Multivar. dengan Progr. SPSS, 2011.

[3] C. F. Baum, A. Chakraborty, and B. Liu, "The impact of macroeconomic uncertainty 
on firms' changes in financial leverage," Int. J. Financ. Econ., 2010.

[4] S. \&\#13; W. Rahma, and A. D. Buchdadi, "Firm Performance, Corporate Governance, and Executive Compensation in Financial Firms: Evidence from Indonesia," SSRN Working Paper Series. 2011.

[5] S. Achchuthan, R. Kajananthan, and others, "Corporate Governance practices and Working Capital Management Efficiency: Special Reference to Listed Manufacturing companies in \{SriLanka\}," Inf. Knowl. Manag., 2013.

[6] Istianingsih, "Impact of firm characteristics on CSR disclosure: Evidence from Indonesia stock exchange," Int. J. Appl. Bus. Econ. Res., 2015.

[7] I. Widigdo, "EFFECT OF CORPORATE SOCIAL PERFORMANCE, INTELLECTUAL CAPITAL, OWNERSHIP STRUCTURE, AND CORPORATE GOVERNACE ON CORPORATE PERFORMACE AND FIRM VALUE (Studies on Companies listed in the SRI-KEHATI Index)," Int. J. Business, Econ. Law, 2013.

[8] M. Mulyono, A. T. Suprapto, and D. Prihandoko, "The Effect of Corporate Governance and Firm Performance on Stock Price: An Empirical Study on Indonesia Stock Exchange,” Binus Bus. Rev., 2018.

[9] C. A. Utama and S. Utama, "Corporate governance, size and disclosure of related party transactions, and firm value: Indonesia evidence," Int. J. Discl. Gov., 2014. 